\title{
Evaluation of the genotoxic potential of water impacted by acid mine drainage from a coal mine in Mpumalanga, South Africa, using the Ames test and Comet assay
}

\author{
Oluwafikemi T lji', Emmanuel Mfotie Njoya', Balungile Madikizela', Jan G Myburgh'1 and Lyndy J McGaw ${ }^{1}$ \\ 'Department of Paraclinical Sciences, Faculty of Veterinary Science, University of Pretoria, Private Bag X04, Onderstepoort 0110, \\ Pretoria, South Africa
}

Several potential genotoxins found in water samples arise from anthropogenic activities. Acid mine effluent resulting from coal mining poses serious environment concerns all over the world. The use of toxicity tests to evaluate the quality of streams add value by providing site-specific toxicological data. Treatment systems such as the use of natural wetlands (passive) or conventional physical and chemical pH-neutralised processes (active) are employed mainly to meet certain water quality guidelines. Nonetheless, potential genotoxins or residues remain which influence the quality of discharged effluents. The objective of this study was to evaluate the genotoxic potential of acid mine drainage (AMD) released into a natural stream following treatment by passive and active methods. This study aimed to identify the extent of AMD mutagenicity and genotoxicity to African Vero monkey kidney cell line and a fish gill cell line (RTgill-W1) using two assays, the Ames test, and the comet assay, as a rapid and effective screening tool. The Ames test performed without metabolic activation using Salmonella typhimurium TA98 and TA100 strains showed no indication of mutagenicity in the water samples tested. Differing results were however obtained for the comet assay using the African Vero monkey kidney cell line and a fish gill cell line (RTgill-W1), which revealed DNA fragmentation and variations in morphologies indicative of genotoxicity in the water samples following the two treatment processes. A significant reduction in DNA damage was observed in water samples following active treatment of the AMD, evidenced by reduced damage frequency and a lowered comet score. This bioassay confirms the urgency of integrating high-throughput screening in aquatic toxicity assessment at genetic levels, giving further evidence that in-vitro bioassays can be incorporated for use in short-term genotoxicity assays. The result suggests that the comet assay proved sensitive at detecting genotoxicity, supporting the integration of this into environmental monitoring frameworks targeted at AMD-contaminated sites.
CORRESPONDENCE

Oluwafikemi T lji

EMAIL

fikemi7@gmail.com

\section{DATES}

Received: 13 December 2019

Accepted: 4 October 2021

\section{KEYWORDS}

coal mining

acid mine drainage

in vitro cell culture

DNA damage

genotoxicity

\section{COPYRIGHT}

(c) The Author(s)

Published under a Creative

Commons Attribution 4.0

International Licence

(CC BY 4.0)

\section{INTRODUCTION}

Several stressful conditions arising from pollution influence the overall health of the aquatic ecosystem, mostly because water bodies end up being the ultimate destination of most pollutants (Zalasiewicz et al., 2010); in South Africa, contamination of water resources resulting in pollution remains a major threat to water resource sustainability (CSIR, 2010). Since the 1980s, chemical monitoring of South Africa's water resources has been well established (Huizenga, 2011), with efforts focused on assessing a range of parameters, such as salts and nutrients (Griffin et al., 2014). However, as part of the River Health Programme, biomonitoring through aquatic toxicity testing has been proposed as an important management and screening tool, that provides water quality information linked to ecological risk in the receiving ecosystem (Scherman et al., 2004). Efforts are therefore in place to move toxicological testing from an ad-hoc basis (DWA, 2013) to being additional tools for use in management of resource quality in South African freshwater systems (Pearson et al., 2015), proposing a proactive intervention to create desired change that supports ecosystem services (Wepener and Chapman, 2012).

Worldwide, mine effluents affect an estimated $19300 \mathrm{~km}$ of streams and rivers, as well as approximately 72000 ha of lakes and reservoirs, causing serious damage to natural waters (Johnson and Hallberg, 2005). The Mpumalanga area hosts $80 \%$ of South Africa's coal mines. The seepage and discharge arising from coal mines make their way into water bodies, causing serious water quality deterioration (Duruibe, 2007). AMD contributes a significant threat to South Africa's environment, because pollution resulting from it places pressure on freshwater systems and its resources, with possible toxic interactions in aquatic systems (Jarvis and Younger, 2001).

The country faces major problems with regards to the management and treatment of contaminated mine-water in both operational and abandoned mines (Schwab, 2002), and in many cases mines are operated beyond capacity design (NWSMP, 2019). Several mines in South Africa employ the use of neutralisation technologies such as limestone and sodium hydroxide to precipitate metals out of the system as metal hydroxides (Günther, 2003) to achieve a neutralised alkaline mixture displaying higher $\mathrm{pH}$ and lower salts (Akcil and Koldas, 2006). Insufficient processing capacities at neutralisation plants sometimes ensue, and un-neutralised AMD and $\mathrm{pH}$-neutralised AMD is often co-released into receiving streams; consequently, metals such as copper $(\mathrm{Cu})$, zinc $(\mathrm{Zn})$, aluminium $(\mathrm{Al})$, ferrous iron $(\mathrm{Fe})$, and manganese $(\mathrm{Mn})$ become easily accessible to surrounding aquatic organisms (Jennings et al., 2008).

Complex chemical mixtures as AMD often elicit unknown cellular and genetic interactions (USEPA, 2000a). Claxton et al. (1998) reported that the United States environment annually receives millions of pounds of genotoxic and/or carcinogenic industrial wastes, and Balch et al. (1995) reported a 
prevalence of tumours in fish inhabiting rivers and lakes of industrialised areas in the US and Europe. Several publications have reported genotoxicity arising from mines (Menezes et al., 2015; Gusso-Choueri et al., 2016). Da Silveira et al. (2009) described DNA damage in Geophagus brasiliensis exposed to both un-neutralised and $\mathrm{pH}$-neutralised AMD, indicating cellular genotoxicity. DNA fragmentation was reported in kidney of fishes, Channa punctata (Bloch), exposed to AMD (Talukdar et al., 2017) and genetic toxicity was established in fish fauna of Simsang River, India, caused by AMD from coal mines (Talukdar, 2016).

Although there have been abundant scientific studies on the environmental impact of AMD, many of these have focused on the integrated effects on fauna, single compound toxins, habitat, and physical environmental degradation (Gerhardt et al., 2004) Others have addressed the presence of specific algal communities, the presence of chironomids (midge flies), detection of iron hydroxides, $\mathrm{pH}$ data and the physiological degeneration of fish species (Jennings et al., 2008; Steyn et., 2019), with an absence of inquiries dealing with toxicity at a cellular level of organisation.

The study aimed to fill this knowledge gap by evaluating the genotoxic potential to fish (RTgill-W1) and mammalian cell lines (Vero monkey) exposed to passively neutralised and actively neutralised AMD, as biomarkers of exposure using in-vitro techniques. To accomplish this, the comet assay and the Ames test were used as a high-throughput assays, offering a novel and complementary South African perspective in the evaluation of the impacts of AMD as an environmental contaminant in a cellular system.

The comet assay, or single cell gel electrophoresis, detects DNA damage induced by alkylating, intercalating or oxidative agents (Cotelle and Férard, 1999). The Salmonella gene mutation assay or Ames test has likewise been used to assess mutagenic activity of wastewater (Stahl, 1991). Both the Ames and comet assays have been recommended as effective mutagenic and genotoxicity assays (Grummt, 2000). Since South Africa has been identified as a water-stressed country, testing of polluted water for genotoxicity may become a routine requirement for industrial wastewater discharge permits, because DNA damage and mutation in water samples would provide basic information for further risk assessment of water sources to give an understanding of the potential effects posed to humans.

\section{METHODOLOGY}

\section{Study area}

The study site chosen was a receiving stream established downstream of a colliery, Kromdraai $\left(25^{\circ} 46^{\prime} 05.5^{\prime \prime}\right.$ S; $29^{\circ} 07^{\prime}$ 15.5” E), in the Highveld region of Mpumalanga Province, South Africa, close to eMalahleni (previously known as Witbank), and within the Olifants River catchment area. The bulk of the mining conducted in the region is by open-cast operations. Kromdraai has a relatively high topographic elevation; run-off usually drains from mining areas and main streams all flow away from mining areas.

\section{Background and pH-neutralisation technology implemented in the study area}

The study was conducted where AMD water discharges into a receiving stream located approximately $13 \mathrm{~km}$ downstream of an active mine, and the site was selected based on the stream order, depth, accessibility, and stream characteristics (outflow from a wetland), and the fact that it is mainly impacted by AMD and relatively free of other influences such as agricultural runoff and human sewage. Effluent discharge outflowing from the mine undergoes passive treatment (flows through a wetland). Active treatment by in-stream dosing of neutralising agent $(\mathrm{NaOH})$ is carried out to increase water $\mathrm{pH}$ and precipitate metals as hydroxides, thus improving water quality.

\section{Sample collection}

Three samples of effluent were collected in September 2014. Sampling was performed according to the recommended standard method (ISO 5667-5). Water samples were collected from two points: samples collected undergoing passive treatment immediately following a wetland were termed untreated (U); water samples collected after active treatment, beyond the point of an instream neutralising process, were termed treated (T). Water samples were transported to the laboratory in $500 \mathrm{~mL}$ polypropylene bottles according to commonly accepted sampling procedures (EPA, 2000). The samples were filtered through 0.2 $\mu \mathrm{m}$ and $0.45 \mu \mathrm{m}$ low protein binding cellulose acetate membrane filters to remove organic material present and kept in the dark at $4^{\circ} \mathrm{C}$ in the refrigerator for genotoxicity assays. The maximum holding capacity for water samples before assaying was 2 weeks.

In-situ measurements of temperature, dissolved oxygen and $\mathrm{pH}$ were conducted at the water sampling points along the course of the stream using a portable multi-meter (HACH HQd, USA). Water samples for analysis were immediately sent to Analytical Services, Chemistry Department, CSIR, Pretoria. The colorimetry methods were used to determine nitrate and nitrite, ammonia, nitrogen, orthophosphate, and phosphate. Metals (aluminium, arsenic, chromium, copper, iron, mercury, silicon, and zinc) were measured using inductively coupled plasma atomic emission spectrometry and inorganic constituents using the ICPAES method ( $\mathrm{Ca}, \mathrm{Mg}, \mathrm{K}, \mathrm{Na}, \mathrm{Cl}$, and sulphates). Analyses were all performed according to the methods of the American Public Health Association (APHA, 1995)

\section{Cell cultivation}

Stock cultures of Vero monkey kidney cells were grown in closed, $75 \mathrm{~cm}^{2}$ filter-cap flasks at $37^{\circ} \mathrm{C}$ in Minimal Essential Medium (MEM, Sigma-Aldrich, USA), supplemented with 0.1\% gentamicin (Virbac, South Africa) and 5\% foetal calf serum (FCS, Highveld Biological South Africa). Cells of a sub-confluent culture were harvested, and $5 \times 10^{4}$ cells/mL plated in $25 \mathrm{~cm}^{2}$ flasks which were incubated for $24 \mathrm{~h}$ at $37^{\circ} \mathrm{C}$ in a $95 \%$ air $5 \% \mathrm{CO}_{2}$ humidified environment. The RTgill-W1 cell line (ATCC CRL2523 $3^{\mathrm{ma}}$ ) was cultured in Leibovitz's L15 medium (Sigma-Aldrich, USA) supplemented with $10 \%$ foetal bovine serum (FBS, Highveld Biological South Africa) in atmospheric air at $20^{\circ} \mathrm{C}$, plated in $25 \mathrm{~cm}^{2}$ flasks at $0.7 \times 106$ cells $/ 4 \mathrm{~mL}$.

\section{In-vitro comet assay}

The cell lines (Vero and RTgill-W1) previously maintained for $24 \mathrm{~h}$ for a complete cell cycle were exposed to $\mathrm{pH}$-adjusted (7.3), syringe-filtered $(0.22 \mu \mathrm{m}$ membrane) AMD water samples in $25 \mathrm{~cm}^{2}$ flasks. Fresh media was prepared from either powdered MEM for Vero cells or powdered L-15M for RTgill-W1 cells using syringe-filtering $(0.22-\mu \mathrm{m}$ membrane) to obtain sterile water samples. Either $75 \%$ or $50 \%$ concentration test water samples were prepared for exposure to the cells. Only the RTgill-W1 cells were exposed at both concentrations, and Vero cells were exposed only at $50 \%$ concentration due to cell availability. Milli-Q water served as negative control while $2 \mathrm{mM}$ ethyl methane sulfonate (EMS; SigmaAldrich), known to induce DNA damage, was used as positive control. The cells were incubated along with the test agents (water samples in a blind fashion) for $24 \mathrm{~h}$ at $37^{\circ} \mathrm{C}$ for Vero and $20^{\circ} \mathrm{C}$ for RTgill-W1 cell lines, and the assays were performed in triplicate.

For the comet assay, the standard alkaline comet assay method described by Singh et al. (1988) was followed. After culture medium was discarded from the flasks, the cells were washed twice with $5 \mathrm{~mL}$ PBS, and trypsinised (0.25\% trypsin-EDTA). The trypsinising process was stopped by adding fresh culture medium supplemented with serum. The contents were homogenised and centrifuged in sterile centrifuge tubes at $1000 \mathrm{r} / \mathrm{min}$ for $5 \mathrm{~min}$ 
and re-suspended in phosphate-buffered saline (PBS) to a final concentration of between 10000 and 15000 cells/mL. Cell viability was determined using trypan blue, allowing only a minimum of $80 \%$ viability for progression of experiments.

$10 \mu \mathrm{L}$ of the cell suspension mixed with $300 \mu \mathrm{L}$ of $0.8 \%$ pre-heated low melting point agarose (in PBS), was spread over coated $1 \%$ normal melting agarose (NMA) pre-treated super frosted microscope slides, which were placed on ice for $10 \mathrm{~min}$ for ease of adhesion, until the agarose cell mixture solidified. The slides were transferred into lysis buffer $(2.5 \mathrm{M} \mathrm{NaCl}, 100 \mathrm{mM}$ EDTA, $10 \mathrm{mM}$ Tris, and $\mathrm{NaOH}$ pellets: $\mathrm{pH} 10$ ). This was placed overnight in the dark in the fridge at $4^{\circ} \mathrm{C}$ and rinsed twice with denaturation buffer (0.3 M NaOH and $1 \mathrm{mM}$ EDTA). To unwind DNA, slides were placed for a further $40 \mathrm{~min}$ at $4^{\circ} \mathrm{C}$ using the same buffer solution $(500 \mathrm{~mL})$ within the electrophoresis chamber and electrophoresis was performed in a pre-cooled $\left(4^{\circ} \mathrm{C}\right)$ horizontal electrophoresis tank for $20 \mathrm{~min}$ at 25 volts and $300 \mathrm{~mA}$.

Following electrophoresis, the slides were placed in neutralisation buffer (0.4 M Tris-HCl, pH 7.5), and subsequently in ice-cold methanol for $10 \mathrm{~min}$. Dry slides were stained with ethidium bromide $(10 \mu \mathrm{g} / \mathrm{mL}$ in water) for $5 \mathrm{~min}$ and analysed for comets. 100 nuclei images were selected randomly for analysis (50 nuclei per slide, in triplicate), which were visually classified into one of 5 classes of damage: zero (no damage) to 4 (maximum damage), according to the methodology proposed by Collins (2004).

The total damage in the cells was determined as the comet score using the formula:

$$
\begin{gathered}
{[(\text { Class } 0) \times 0]+[(\text { Class } 1) \times 1]+} \\
\frac{[(\text { Class } 2) \times 2]+[(\text { Class } 3) \times 3]+[(\text { Class } 4) \times 4]}{\text { Total number of cells counted per side }}
\end{gathered}
$$

The number of damaged cells (damage frequency) was analysed based on the ability of the tail to migrate under electrophoresis, such that its intensity and size are suggestive of the index of fragments generated by the exposure to genotoxic agents.

\section{The Ames test}

Mutagenicity in samples was assessed using the Salmonella plate incorporation assay according to the standard test protocol of Maron and Ames (1983) without exogenous metabolic activation (addition of S9 microsomal fraction). Salmonella typhimurium test strains TA98 and TA100 were used to investigate the mutagenic activity of water samples. Strain TA100 is sensitive for detecting base-exchange mutations; strain TA98 can detect frame shift mutagens (Mortelmans and Zeiger, 2000). $100 \mu \mathrm{L}$ of Salmonella typhimurium strains TA98 and TA100 were inoculated into $10 \mathrm{~mL}$ Oxoid nutrient broth No. 2, and then incubated at $37^{\circ} \mathrm{C}$ for $16 \mathrm{~h}$. $100 \mu \mathrm{L}$ whole water test samples (AMD water), negative (sterile distilled water) and positive control (4-nitroquinoline-N-oxide, at a concentration of $2 \mu \mathrm{g} / \mathrm{mL}$ ) were dispensed in allocated sterilised culture tubes and $500 \mu \mathrm{L}$ phosphate buffer $(50 \mathrm{mM}, \mathrm{pH} 7.5)$ was then added, followed by addition of $100 \mu \mathrm{L}$ of bacterial strain. To $100 \mathrm{~mL}$ top agar (Difco), placed in a water bath at $50^{\circ} \mathrm{C}, 10 \mathrm{~mL}$ biotin/histidine mixture was added, and $2 \mathrm{~mL}$ aspirated into the test tube containing the test samples.

Test tubes containing samples were placed in a water bath at $37^{\circ} \mathrm{C}$, mixed thoroughly by vortexing, poured onto the agar plates, and then incubated for $48 \mathrm{~h}$ at $37^{\circ} \mathrm{C}$. Mutagenicity was accessed through bacterial colony counts after the 48-h incubation period using a colony counter, and results expressed as the mean ( \pm standard error) number of the revertant colonies per plate. A positive mutagenic response in the Ames test is recorded when there is doubling of the number of revertant colonies at any concentration of the test sample compared to the negative control (Verschaeve and Van Staden., 2008).

\section{Statistical analysis}

All assays were performed in triplicates and the result presented as mean \pm SD (standard deviation). Statistical analysis was carried out using a one-way analysis of variance (ANOVA) followed by Hartley's $\mathrm{f}$ test for equal variance. Inter-test variations were assessed using the appropriate Student's t-test. This data analysis was performed using OpenEpi, open-source calculator Version 3. $P$ value was set at $p<0.05$.

\section{RESULTS}

\section{Physico-chemistry of water samples}

Table 1 showed values for the physicochemical parameters measured, and the target water quality range (TWQR) determined

Table 1. Physicochemical parameters of the water samples and target water quality range (TWQR)

\begin{tabular}{lcccc}
\hline Parameters & Units & Untreated (U) & Treated (T) & TWQR \\
\hline $\mathrm{pH}$ & & $3.2 \pm 0.70^{\mathrm{a}}$ & $8 \pm 0.57$ & $6-9$ \\
$\mathrm{DO}$ & $\%$ & $6.9 \pm 0.20$ & $4.9 \pm 0.10$ & $\mathrm{NA}$ \\
Conductivity & $\mathrm{MS} / \mathrm{m}$ & $320 \pm 7.77$ & $326 \pm 0.12$ & $70-250$ \\
Alkalinity & $\mathrm{mg} \mathrm{CaCO} / \mathrm{L}$ & $2.75 \pm 3.18$ & $64 \pm 55.1^{\mathrm{a}}$ & $\mathrm{NA}$ \\
$\mathrm{COD}$ & $\mathrm{mg} \mathrm{O} / \mathrm{L}$ & $10.5 \pm 0.7$ & $10.5 \pm 0.7$ & $\mathrm{NA}$ \\
$\mathrm{Mg}$ & $\mathrm{mg} / \mathrm{L}$ & $152 \pm 2.12$ & $170 \pm 0.70$ & $\mathrm{NA}$ \\
$\mathrm{Na}$ & $\mathrm{mg} / \mathrm{L}$ & $43 \pm 0.20$ & $120 \pm 0.14^{\mathrm{a}}$ & $\mathrm{NA}$ \\
$\mathrm{Ca}$ & $\mathrm{mg} / \mathrm{L}$ & $475 \pm 0.35$ & $561 \pm 0.12$ & $\mathrm{NA}$ \\
$\mathrm{Cl}$ & $\mathrm{mg} / \mathrm{L}$ & $3.5 \pm 2.12$ & $3.5 \pm 2.12$ & $\mathrm{NA}$ \\
$\mathrm{Sulphate}$ & $\mathrm{mg} / \mathrm{L}$ & $2169 \pm 0.98$ & $2336 \pm 3.73$ & 200 \\
$\mathrm{NH}{ }_{3}$ & $\mathrm{mg} / \mathrm{L}$ & $6.7 \pm 4.38$ & $6.45 \pm 4.03$ & $0.5-2.5$ \\
$\mathrm{OP}$ & $\mathrm{mg} / \mathrm{L}$ & $0.15 \pm 0.07$ & $0.15 \pm 0.07$ & $\mathrm{NA}$ \\
$\mathrm{Nitrate}(\mathrm{v})+$ nitrite (iii) & $\mathrm{mg} / \mathrm{L}$ & $2.3 \pm 0.2 .4$ & $3.5 \pm 4.10$ & $\mathrm{NA}$ \\
$\mathrm{Phosphate}$ & $\mathrm{mg} / \mathrm{L}$ & $0.22 \pm 0.03$ & $0.22 \pm 0.03$ & $\mathrm{NA}$ \\
$\mathrm{Al}$ & $\mathrm{mg} / \mathrm{L}$ & $7.55 \pm 0.9^{\mathrm{a}}$ & $0.15 \pm 0.01$ & 0.005 \\
$\mathrm{Fe}$ & $\mathrm{mg} / \mathrm{L}$ & $0.36 \pm 0.03^{\mathrm{a}}$ & $0.015 \pm 0.01$ & $\mathrm{NA}$ \\
$\mathrm{Mn}$ & $\mathrm{mg} / \mathrm{L}$ & $65 \pm 0.14^{\mathrm{a}}$ & $39 \pm 6.36$ & 0.014 \\
$\mathrm{Zn}$ & $\mathrm{mg} / \mathrm{L}$ & $3.35 \pm 1.06^{\mathrm{a}}$ & $0.04 \pm 0.02$ & 0.08 \\
$\mathrm{Ar}$ & $\mathrm{mg} / \mathrm{L}$ & $0.01 \pm 0.01$ & $0.01 \pm 0.01$ & 0.01 \\
$\mathrm{Cr}$ & $\mathrm{mg} / \mathrm{L}$ & $0.01 \pm 0.01$ & $0.01 \pm 0.01$ & $0.007-0.012$ \\
$\mathrm{Cu}$ & $\mathrm{mg} / \mathrm{L}$ & $0.03 \pm 0.03$ & $0.03 \pm 0.03$ & $0.003-0.0012$ \\
\hline $\mathrm{ind}$ & &
\end{tabular}

a indicates significant difference between $U$ and $T$ at $\mathrm{p}<0.05 ; \mathrm{OP}$ - orthophosphate; $\mathrm{COD}$ - chemical oxygen demand; $D O$ - dissolved oxygen 
from water samples from the site. Results of the $\mathrm{pH}$ and electrical conductivity (EC) values from the two collection points showed that values obtained were above TWQR acceptable limits. Values recorded for metals such as $\mathrm{Al}, \mathrm{Mn}$, and $\mathrm{Zn}$ were far higher in passively treated $(\mathrm{U})$ than in $(\mathrm{T})$ samples, values obtained for metals detected were above South Africa's TWQR guideline level for metals in aquatic systems. Values for total alkalinity and hardness indicate that carbonates/bicarbonates and $\mathrm{Ca}, \mathrm{Na}, \mathrm{Mg}$ were the dominant ions. Of the measured total salt variables, high ammonium and sulphates stood out, indicative of high contamination within the aquatic system.

\section{Mutagenic potential of water samples}

The results of the Ames test showed that the mutagenic activities expressed as induction factors (multiples of the background levels) using the TA98 and TA100 strains were all $<2$. Neither water samples produced a response that was at least twice as high as that of the negative control. Assays with strains TA100 and
TA98 generally had lower levels of base-substitution mutagens but displayed slight variation when comparing induction factors up to $1.7 \mathrm{x}$ with TA100 displaying a higher degree of sensitivity $(p<0.05)$ to $\mathrm{U}$ compared to T (Table 2).

\section{DNA damage in cells treated with water samples}

The results of the comet assay with Vero cells showed that the test water samples ( $\mathrm{U}$ and $\mathrm{T}$ at 50\%) exhibited an increase in DNA damage which caused a significant increase in \% DNA tail intensity and comet score relative to the negative control $(p<0.05$; Fig. 1$)$. The damage frequency was highest in $\mathrm{U}$, which had metal content $(\mathrm{Al}$, $\mathrm{Mn}$, and $\mathrm{Zn}$ ) values that were higher than seen in T. Furthermore, similar trend was observed using the RTgill-W1 cell line (at 75\% and $50 \%$ ) which presented with greater damage frequency and higher comet score in U compared to T (Fig. 2). The distribution of comet in cells (Fig. 3) showed that the negative control had the most cells which fell into Class 0 , graded $0<1<2<3<4$, and $\mathrm{U}$ produced more damaged cells (comet score of $1-4$ ) than $\mathrm{T}$.

Table 2. Number of revertant colonies of Salmonella typhimurium strains TA98 and TA100 induced by untreated and treated AMD water samples from a coal mine in Mpumalanga province, South Africa

\begin{tabular}{lcccc}
\hline Sample & \multicolumn{2}{c}{ TA98 } & \multicolumn{2}{c}{ TA100 } \\
\cline { 2 - 3 } Milli-Q water & Revertant/plate & Induction factor & Revertant/plate & Induction factor \\
Untreated & $17 \pm 0$ & 1 & $159 \pm 3$ \\
Treated & $26 \pm 1$ & $1.52 \pm 0.02$ & $276 \pm 1$ \\
4NQO & $27 \pm 1$ & $1.58 \pm 0.02$ & $163 \pm 8$ \\
\hline
\end{tabular}

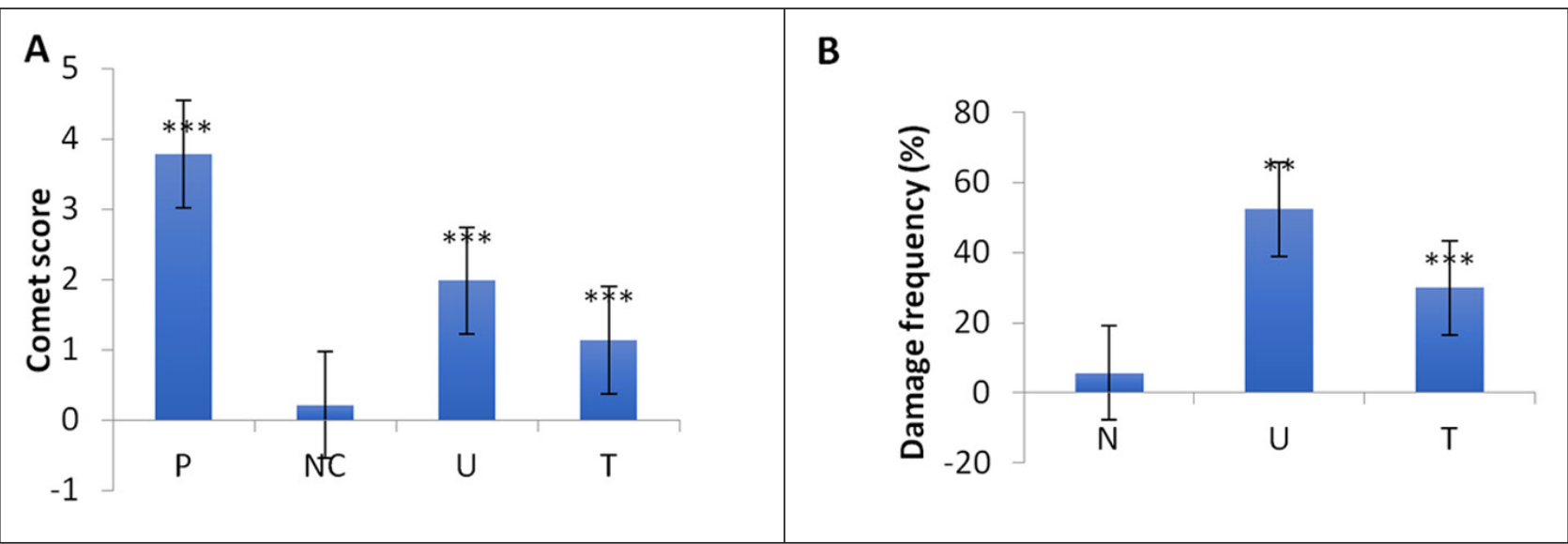

Figure 1. Damage (A) and frequency (B) indices of DNA damage to Vero cells exposed to $50 \%$ water sample impacted by AMD from a coal mine. PC - positive control, NC - negative control, $\mathrm{U}$ - untreated, $\mathrm{T}$ - treated water samples, ${ }^{* *} p \leq 0.01,{ }^{* * *} p \leq 0.001$

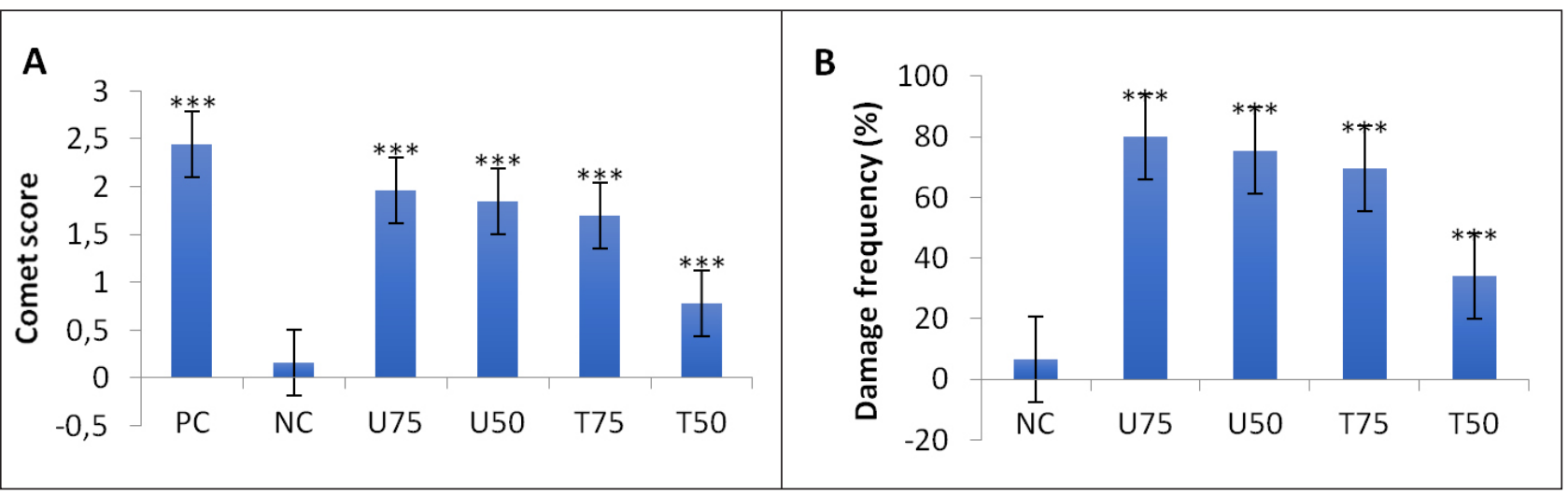

Figure 2. Damage (A) and frequency (B) indices of DNA damage to RTgills-W1 cells exposed to water sample impacted by AMD from a coalmine at $75 \%$ and 50\%: PC - positive control, NC - negative control, $\mathrm{U}$ - untreated, $\mathrm{T}$ - treated water samples, ${ }^{* * *} p \leq 0.001$ 


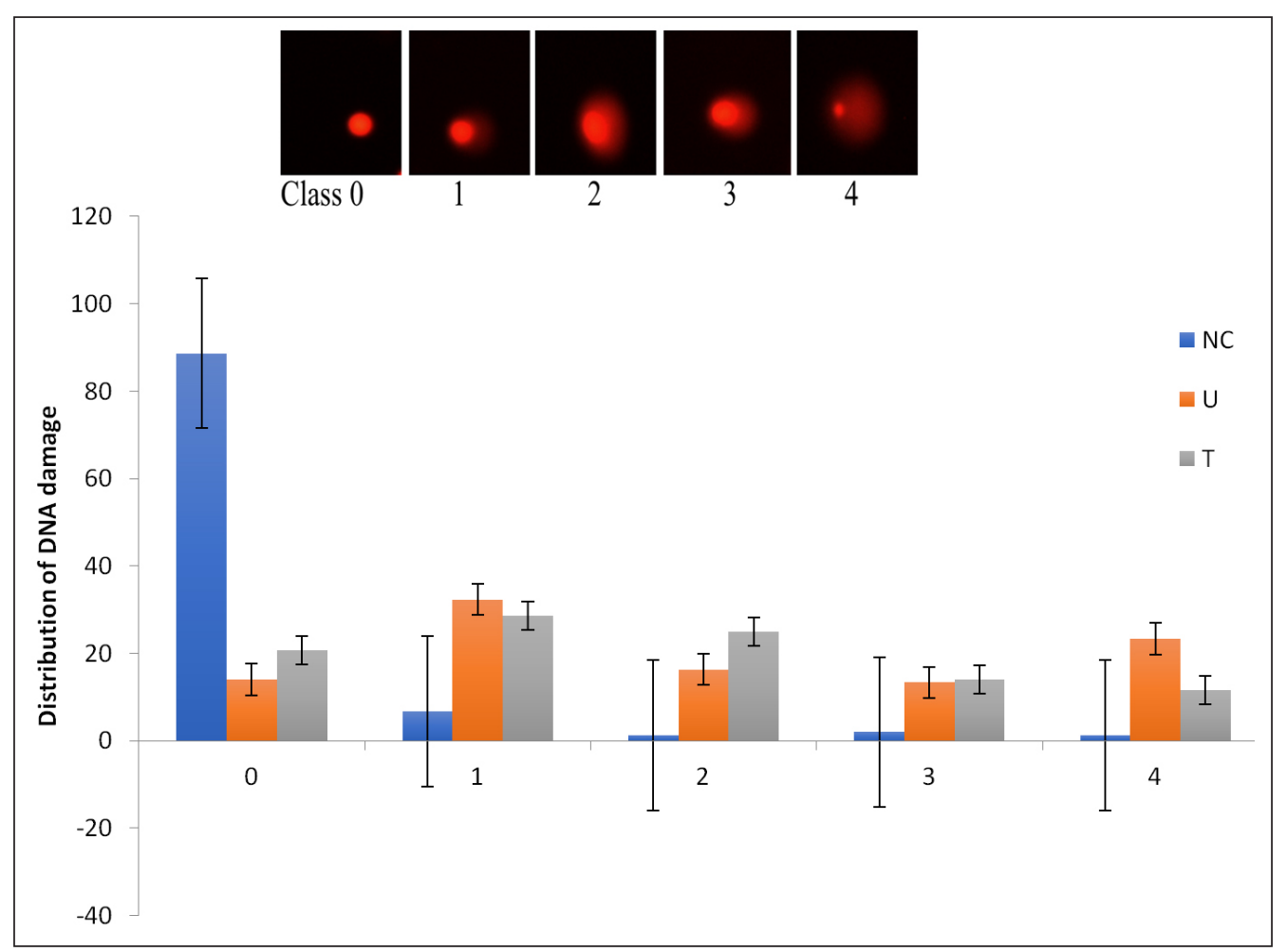

Figure 3. DNA damage from Class 0 (no damage) to Class 4 (maximum damage), according to the size and shape of the tail. Mean values of nuclear DNA damage distribution in Vero cells exposed to water samples at 50\%: NC - negative control, $\mathrm{U}$ - untreated, $\mathrm{T}$ - treated. Results are an average of 3 experiments $(n=100)$.

The water samples tested displayed higher genotoxic potential compared to the negative control (Milli-Q water) at the concentrations tested using the RTgill-W1 cell line. A statistically significant reduction in damage frequency and/or comet score $(p<0.001)$, however, was observed between the two concentrations tested $(75 \%$ and $50 \%)$ in T, but this was not reported for U. Distribution of comet cells in RTgill-W1 cells following exposure to water samples (Figures 4 and 5) indicated that comet formation order was $\mathrm{N}<\mathrm{T}<\mathrm{U}$.

Vero cells presented with slightly higher comet score and, consequently, greater damage frequency compared to the RTgillW1 cell lines at the same concentration $(p<0.001)$. Difference in treatment technologies showed a reduction in genotoxicity $(\mathrm{U}$ and $\mathrm{T})$ in water samples tested at the same concentration range using both cells (Fig. 6).

\section{DISCUSSION}

By convention, physical and chemical monitoring of water quality give information about the presence of substances and the concentrations at which they occur; however, highly relevant details about potential toxicological or ecological effects of such waters are ignored. Contaminants from mines generating AMD include sulphates, acidity, salinity, and metals, which contribute to surface water pollution (Oberholster et al., 2012). Proper management of surface waters for adequate protection of aquatic ecosystems requires a robust system that integrates not only chemical, but biological and cellular analyses to detect impact within aquatic systems (Ohe et al., 2004), especially regarding stress-related pollution and potential genotoxic substances in water which cause DNA damage (Klobucar et al., 2003).

Ohe et al. (2004) proposed that mutagenicity/genotoxicity assays could be a useful water-monitoring tool. Both the Ames and comet assays have been suggested as effective genotoxicity assays (Nagarathna et al., 2013), with some studies (Radić et al., 2014 Amaeze et al., 2014) suggesting genotoxicity assays as a tool for biomonitoring of aquatic pollution.
The physico-chemical analyses (Table 1) revealed that effluent collected immediately following the wetland (U) had significantly higher metal levels and acidity compared to $\mathrm{T}$, an indication of the possible inefficiency of the natural wetland to remove all potentially toxic pollutants, a scenario described by Kalin (2004) as site overload arising from metal adsorption. Wetlands have the potential to improve water quality through processes such as filtration, adsorption, and active plant uptake of metals (USEPA, 2018), and have been used in treatment of wastewater discharges from municipal, industrial and agricultural sources, as well as surface mine runoff and other sources of water pollution (Younger et al., 2002).

Reports on water quality parameters showed declining quality due to AMD, as previously reported by Soucek et al. (2000). These parameters were characteristic of acid precipitation (Rosemond et al., 1992), and/or the presence of heavy metals (Kiffney and Clements., 1994). Using the AMD impact criteria (FWPCA, 1968), the site could be categorised as being highly impacted. Likewise, conductivity, an indirect measurement of pollutant concentration, was high in $\mathrm{U}$ and $\mathrm{T}$, indicative of impact of AMD (DWAF, 1996). Pollutants of interest in AMD reported by Heath et al. (2009) include $\mathrm{Al}, \mathrm{Mn}$ and $\mathrm{Zn}$, which were present in $\mathrm{U}$ and $\mathrm{T}$ at substantial concentrations, a further indication of the extent of AMD pollution at this site. The presence of metals Al, $\mathrm{Mn}$ and $\mathrm{Zn}$ accompanied with added acidity $(\mathrm{H}+)$, could increase metal bioavailability and concomitant mobilisation of metals into solution (USEPA, 2005).

Free metal ions become more bioavailable than when bound to colloidal and/or particulate matter (Batley, 2002). Coetzee (2002) reported $\mathrm{Al}$ as the toxic agent of AMD within the upper Olifants River of South Africa. Salts such as $\mathrm{Ca}, \mathrm{Na}, \mathrm{K}, \mathrm{Mg}$ and sulphates contribute to increased EC. Mining activities increases the propensity for salinisation, which poses a risk to biodiversity, and acts as a stressor for freshwater ecosystems (Millennium Ecosystem Assessment, 2005). 


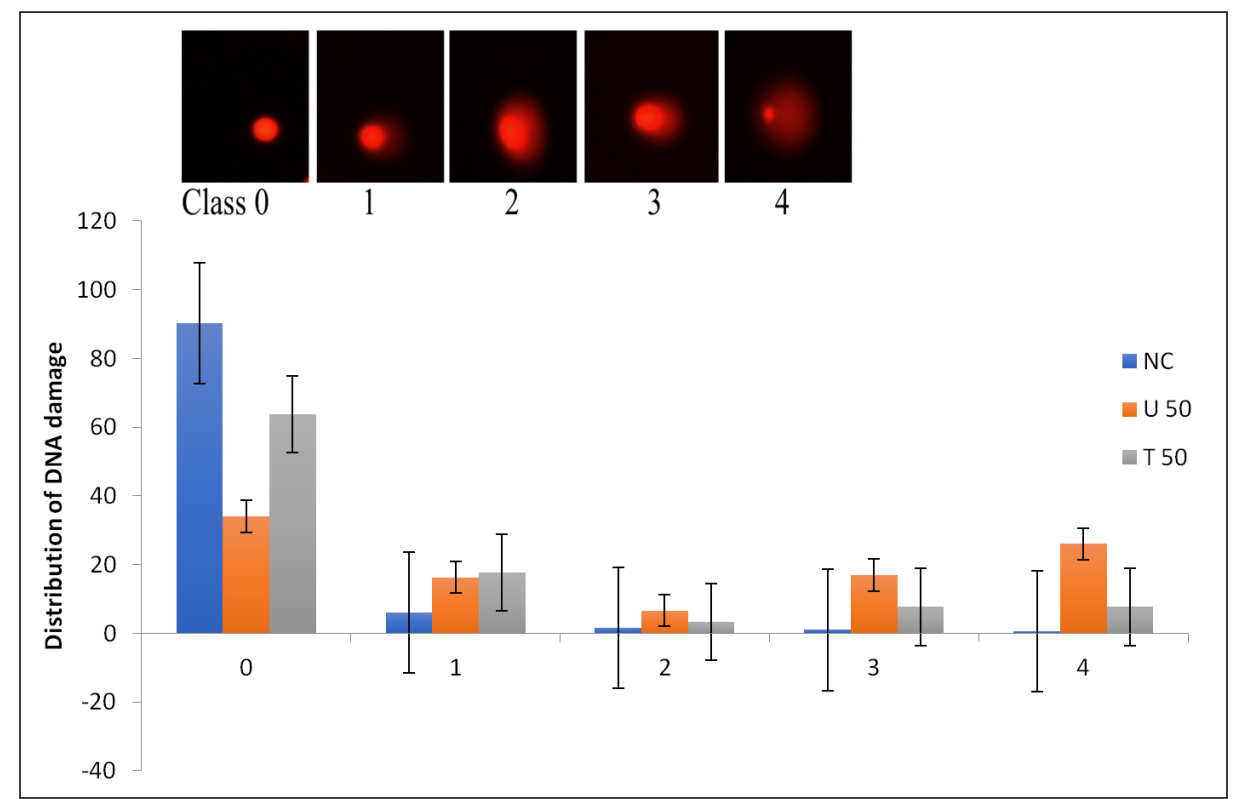

Figure 4. DNA damage from Class 0 (no damage) to Class 4 (maximum damage), according to the size and shape of the tail. Mean values of nuclear DNA damage distribution in RTgill-W1 cells exposed to water samples at 50\%: NC - negative control, U - untreated, T - treated. Results are an average of 3 experiments $(n=100)$.

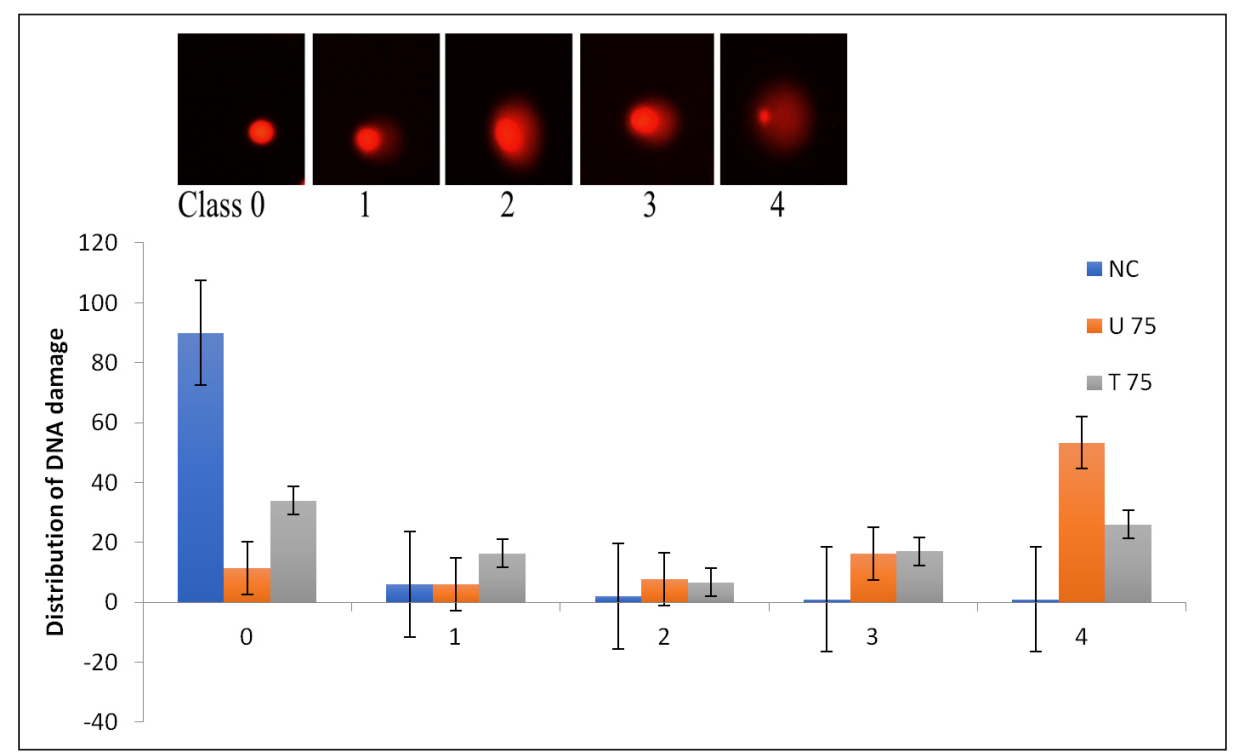

Figure 5. DNA damage from Class 0 (no damage) to Class 4 (maximum damage), according to the size and shape of the tail. Mean values of nuclear DNA damage distribution in RTgill-W1 cells exposed to water samples at 75\%: NC - negative control, U - untreated, T - treated.

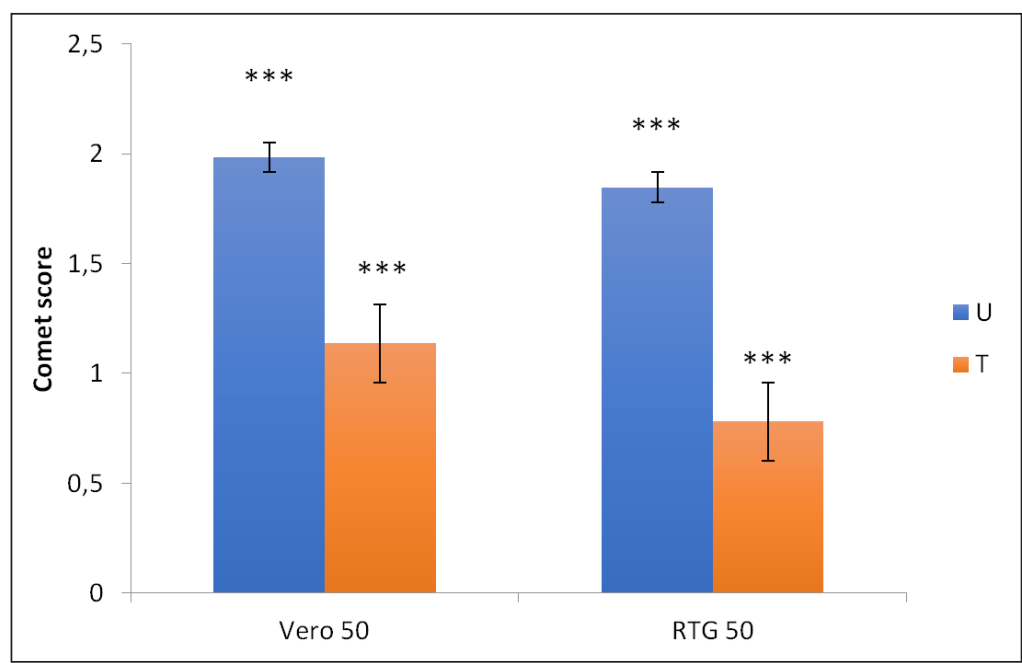

Figure 6. Oxidative damage to DNA comparing differences between untreated $(\mathrm{U})$ and treated $(\mathrm{T})$ water samples in Vero and RTgill-W1 cell lines at $50 \%$ concentration 
The use of species-relevant cell lines such as Vero monkey kidney cells (mammalian cell line) and the RTgill-W1 cells (a fish gill cell line) as in-vitro bioassay to assess the environmental quality of mine effluent impacting a natural water body downstream of a colliery, was explored in our study. RTgill-W1 cell line was chosen for the study because it is derived from the gills, an organ of fish in direct contact with water and consequently the focal site for waterborne toxicant uptake and toxic action. Although several difficulties arise when trying to understand the toxicological evaluation of metal mixtures such as AMD, an established fact points to the chemical nature of AMD being characterised as oxidative agents comprising of oxygen species (Johnson and Hallberg, 2005).

Mutagenicity in water samples was not observed using the Ames test, as induction factor was not $>2$ (Table 2). The reason for this could be that mutagens were not present or detectible because the bacteria strains used do not possess internal metabolic activation enzyme systems and, as such, were not effective at detecting potentially mutagenic compounds in the water samples. Mutagens, especially those that are important to human exposure, are usually biologically inert, requiring metabolic activation to their mutagenic state. While not all genotoxic substances stimulate the establishment of mutations, the Ames test (Maron and Ames, 1983) is still widely used to assess mutagenic activity of wastewater (Stahl, 1991). In addition, use of several Salmonella typhimurium strains in tests could increase the likelihood of detecting a mutagenic chemical.

This study showed an extensive DNA smearing in both cell lines exposed to untreated and treated ( $\mathrm{pH}$-neutralised) AMD at $75 \%, 50 \%$ (RTgill-W1) and $50 \%$ (Vero) concentrations. The water sample $\mathrm{U}$ had considerable genotoxic potential, both in the damage index and the frequency index, when compared to $\mathrm{T}$; although the active treatment method (in-stream $\mathrm{pH}$ neutralisation) significantly reduced DNA damage in T (Figs 1 and 2), this was not enough to prevent observable DNA damage sustained in T. A plausible explanation could be the persistence of non-precipitated substances and/or heavy metals that interact with other solutes to form complexes which remain in the dissolved form, being potentially able to attack nucleic acids (Moralejo and Acebal, 2014). A previous study by Steyn et al. (2019) demonstrated that treated AMD was toxic for up to $7 \mathrm{~km}$ downstream of a treatment plant along Tweelopie stream, failing to effectively protect ecosystem health.

Metals such as $\mathrm{Al}$ and $\mathrm{Zn}$ induce genotoxicity (Godet et al., 1996). Detailed alterations in DNA in the presence of metals, demonstrating a causative link, have been described (Truter et al., 2014). An in-vitro comet assay in RTgill-W1 cells implicated $\mathrm{Cu}$ as the potential genotoxic agent causing ROS formation (Bopp et al., 2008). In this study, the two dilution doses exposed to RTgill-W1 cells displayed similar susceptibility to genotoxicity. A logical explanation would be that genotoxicity in heavily contaminated complex mixtures such as metal-laden AMD may not follow a dose-response pattern, but the testing of further concentrations would be necessary to determine a dose-response curve and descent of low- or no-effect concentrations.

The bioavailability of potent genotoxins following dilution suggests a complex contaminant matrix within this site, which might have been responsible for the interactions that influenced the observed DNA damage. Understanding the toxicological evaluation of complex metal mixtures such as AMD is difficult because a single element or compound may have multiple affinity sites and may display synergistic or antagonistic effects, producing toxic metabolites or damaging DNA (Carpenter et al., 1998).

Conversely, a significant decrease in DNA damage in RTgill-W1 cells was seen following dilution of $\mathrm{T}$ water samples at $75 \%$ and $50 \%$. Madeira et al. (2005) reported that a rise in $\mathrm{pH}$ of the stream, achievable using an instream alkali neutralisation process, resulted in complexation phenomena and subsequent reduction in metal burden, because metals precipitate as metal hydroxides. This conceivably explained the observed significant reduction in DNA damage in T water samples following dilution. Similar observations were reported by Netto et al. (2013), who described that the reduction of acidity and removal of metals resulted in reduction of toxic and genotoxic effects using bioindicator organisms Artemia sp. and Daphnia magna. Tamires et al. (2009) detailed a reduction of genotoxicity in Allium cepa root cells exposed to AMD from coal mining following treatment, as water conditions improved. Likewise, Franklin et al. (2000) reported a decrease in toxicity of effluent from an abandoned uranium mine, to tropical freshwater alga (Chlorella sp.), which was $\mathrm{pH}$ dependent.

Although water chemistry results showed a significant reduction in metals like $\mathrm{Al}, \mathrm{Mn}$, and $\mathrm{Zn}$ following active in-stream $\mathrm{pH}$ neutralization, genotoxicity in cells was sustained. The presence of other potentially toxic agents may have played a role in DNA damage. Wijeyaratne and Wickramasinghe (2020) detected cytotoxicity and genotoxicity in discharged effluents which complied with the standard limits. In this study, the observed genotoxicity in treated water could be due to bioavailable genotoxic substances capable of inducing intracellular generation of ROS, and consequently generating high levels of cellular oxidative damage (Breen and Murphy, 1995).

Reactive oxygen species (ROS) such as hydrogen peroxide $\left(\mathrm{H}_{2} \mathrm{O}_{2}\right)$, superoxide $\left(\mathrm{O}_{2}\right)$ and hydroxyl radical $(\mathrm{OH})$, have been associated with oxidative stress in cells, resulting in DNA damage, cancer, and cellular ageing, amongst other degenerative diseases (Guo et al., 2014). Previous work by our research group detected the generation of ROS using water samples from this site (Iji et al., 2017), in RTgill-W1 and the C3A cell lines. Metals are potent initiators of ROS and are known to enhance oxidative stress and damage to macromolecules through Fenton reactions (Karbownik et al., 2003). Additionally, the presence of sulphates and salts in aquatic environments contributes to stress conditions associated with enhanced ROS generation, which may be implicated in oxidative damage. ROS are also highly reactive with DNA, proteins, carbohydrates, and lipids (Valko et al., 2007).

The level of damage observed in the study was quantified as \%DNA in tail. \%DNA in tail is a representation of single- and double-stranded DNA intensity within the tail region, giving an insight into the kinetics of gDNA unravelling in the presence of harmful substances (Hayashi et al., 2000). Due to comet class scoring data, the study observed a high \%DNA in tail in cell lines exposed to $\mathrm{U}$ and $\mathrm{T}$. Chromosomal changes might be directly related to DNA fragmentation, which has been used by many studies as a biomarker to confirm the presence of a substance causing damage-mediated DNA cleavage (Talukdar et al., 2016)

Results showed that both cell lines detected genotoxins in surface water; the Vero Monkey kidney cell lines, however, showed greater sensitivity. Another study reported a dose-dependent increase in DNA fragmentation observed in primary cultures of rat and human kidney cells exposed to chemicals carcinogenic to rat kidney (Robbiano et al., 2004). Although varying degrees of vulnerability to oxidative damage and ROS formation have been reported in cell lines (Oliveira et al., 2008), the cause is not readily evident, as certain mammalian cell lines are reported to possess a greater degree of metal sensitivity (Freedland et al., 1989). Another reason could be differences in the DNA repair capabilities between cell lines, as Kienzler et al. (2013) reported that RTgill-W1 and RTL-W1 cells possess functioning nucleotide excision repair and photoactivation repair on exposure to UV light. 
Another plausible explanation could be that the Vero cells, which are derived from kidneys, serve as an important target organ for heavy metal toxicity (Gardner et al., 2006; Barbieri et al., 2009).

Demonstrating the applicability of this bioassay in improving the quality of the AMD effluent treated by conventional physical and chemical processes is crucial. This study validates the sensitivity of the comet assay as a rapid technique for measuring DNA damage in individual cells, which is, in fact, more robust than the Ames test which uses prokaryotic organisms (Kosmehl et al., 2000). Furthermore, it confirms an association between DNA damage and mine-water contamination, as previously reported (Menezes et al., 2015; Gusso-choueri et al., 2016).

Routine aquatic and wastewater testing should include genotoxicity (Kosmehl et al., 2004) as a biological tool because of its ability to detect specific effects and their significance in hazard assessment. Since aquatic organisms store pollutants, either directly or by ingestion, genotoxic pollutants may contaminate the aquatic environment or the whole ecosystem, moving up to humans via the food chain (Matsumoto et al., 2006).

\section{CONCLUSIONS}

Evaluating biomarkers of DNA damage in fish and mammalian cells exposed to acid mine drainage, by means of high-throughput assays, offers a new perspective for environmental biomonitoring of South African waters. The goal for water quality should exceed that of neutralising AMD-contaminated waters by increasing $\mathrm{pH}$, decreasing the concentration of available metals, and removing solids, to include the release of water at a quality that supports aquatic life, as this study showed that the presence of chemical compounds and/or heavy metals interacts with cells, possibly through ROS generation, to cause damage. Neutralisation technologies that remove trace amounts of metal and sulphates are recommended as an additional system to the current $\mathrm{NaOH}$ neutralisation technique. Rapid and cost-effective bioassays such as these will help target areas of concern for comprehensive hazard assessment. However, validation of the endpoints for ecological significance may still be required and once this is calibrated it can be used in a more quantitative way.

\section{ACKNOWLEDGEMENTS}

This study was funded by the Department of Paraclinical Sciences (University of Pretoria) and the National Research Foundation (NRF), South Africa (LJM: Incentive Funding for Rated Researchers). OTI is grateful to the Schlumberger Stitching Fund, Netherlands, for a PhD Fellowship.

\section{CONFLICT OF INTEREST}

All authors declare that they have no conflict of interest.

\section{REFERENCES}

AKCIL A and KOLDAS S (2006) acid mine drainage (AMD): causes, treatment, and case studies. J. Clean. Prod. 14 1139-1145. http://dx. doi.org/10.1016/j.jclepro.2004.09.006

AMAEZE NH, SCHNELL S, SOZERI O, ADEBAYO A, OTITOLOJU, EGONMWAN RI, VOLKER MA and BURY NR (2015) Cytotoxic and genotoxic responses of the RTgill-W1 fish cells in combination with the yeast oestrogen screen to determine the sediment quality of Lagos lagoon, Nigeria. Mutagenesis. 30 117-127. https://doi.org/ 10.1093/mutage/geu032

APHA (American Public Health Association) (1995) Standard Methods for the Examination of Water and Wastewater $\left(19^{\text {th }}\right.$ edn). APHA, Washington DC.

AMES BN, DURSTON WE, YAMASAKI E and LEE FD (1973) Carcinogens are mutagens: a simple test system combining liver homogenates for activation and bacteria for detection. Proc. NatI. Acad. Sci. 70 782-786. https://doi.org/10.1073/pnas.70.8.2281
BALCH GC, METCALFE CD and HUESTIS SY (1995) Identification of potential fish carcinogens in sediment from Hamilton Harbour, Ontario, Canada. Environ. Toxicol. Chem. 14 79-91. https://doi.org/ 10.1002/etc. 5620140110

BARBIERI E (2009) Concentration of heavy metals in tissues of green turtles (Chelonia mydas) sampled in the Cananeia estuary, Brazil. J. Oceanogr. 57 243. http://dx.DOI.org/10.1590/S1679-8759 2009000300007

BATLEY GE, BURTON GA JR, CHAPMAN PM and FORBES VE (2002) Uncertainties in sediment quality weight of evidence (WOE) assessment. Hum. Ecol. Risk Assess. 8 1517-1547. https://doi.org/ 10.1080/20028091057466

BOPP SK, ABICHT HK and KNAUER K (2008) Copper-induced oxidative stress in rainbow trout gill cells. Aquat. Toxicol. 86 197-20. https://doi.org/10.1016/j.aquatox.2007.10.014

BREEN AP and MURPHY JA (1995) Reactions of oxyl radicals with DNA. Free Radical Biol. Med. 18 (6) 1033-1077.

CARPENTER DO, ARCARO KF, BUSH B, NIEMI WD, PANG S and VAKHARIA DD (1998) Human health and chemical mixtures: an overview. Environ. Health Perspect. 106 1263-1270. https://doi. org/10.1289/ehp.98106s61263

CHERRY DS, CURRIE RJ, SOUCEK DJ, LATIMER HA and TRENT GC (2001) Integrative assessment of a watershed impacted by abandoned mined land discharges. Environ. Pollut. 111 377-388. https://doi.org/10.1016/S0269-7491(00)00093-2

CLAXTON LD, HOUK VS and HUGHES TJ (1998) Genotoxicity of industrial wastes and effluents. Mutat. Res. 410 237-243. https://doi. org/10.1016/s1383-5742(98)00008-8

COETZEE H, CROUKAMP L, VENTER J and DE WET L (2005) Contamination of the Tweelopie Spruit and environs by water from the Western Basin decant point on Harmony Gold's property. Council for Geoscience Report No. 2005-0148. Council for Geoscience, Pretoria. 28 pp.

COLLINS AR (2004) The comet assay for DNA damage and repair: principle, applications, and limitations. Mol. Biotechnol. 26 249261. https://doi.org/10.1385/MB:26:3:249

CSIR (Council for Scientific and Industrial Research) (2015) A CSIR perspective on water in South Africa. CSIR Report No. CSIR/ NRE/PW/CSIR2011/0012/A. URL: http://www.csir.co.za/nre/docs/ (Accessed 4 March 2015).

DA SILVEIRA FZ, DEFAVERI TM, RICKEN C, ZOCCHE JJ and PICH CT (2009) Toxicity and genotoxicity evaluation of acid mine drainage using Artemia sp. and Geophagus brasiliensis as bioindicators. Proc. 2009 National Meeting of the American Society of Mining and Reclamation: Revitalizing the Environment: Proven Solutions and Innovative Approaches, 30 May - 5 June 2009, Billings, MT.

DWA (Department of Water Affairs, South Africa) (2013) National Water Resource Strategy. $2^{\text {nd }}$ edition. Department of Water Affairs, Pretoria.

DURUIBE JO, OGWUEGBU MOC and EGWURUGWU JN (2007) Heavy metal pollution and human biotoxin effects. Int. J. Phys. Sci. $2112-118$

FRANKLIN NM, STAUBER JL, MARKICH SJ and LIM RP (2000) pHdependent toxicity of copper and uranium to a tropical freshwater alga (Chlorella sp.). Aquat. Toxicol. 48 275-289. https://doi.org/ 10.1016/s0166-445x(99)00042-9

FREEDLAND JH, CIRIOLO MR and PEISACH J (1989) The role of glutathione in copper metabolism and toxicity. J. Biol. Chem. 264 5598-5605.

GARDNER SC, FITZGERALD SL, VERGAS BA and RODRIGUEZ LM (2006) Heavy metal accumulation in four species of sea turtles from the Baja California peninsula, Mexico. Bio Metals. 19 91-99. https:// doi.org/10.1007/s10534-005-8660-0

GERHARDT A, JANSSENS DE BISTHOVEN L and SOARES AM (2004) Macroinvertebrate response to acid mine drainage: community metrics and on-line behavioural toxicity bioassay. Environ. Pollut. $130263-274$.

GODET F, BABUT M, BURNEL D, VEBER A-M and VASSEUR P (1996) The genotoxicity of iron and chromium in electroplating effluents. Mutat. Res. 370 19-28. https://doi.org/10.1016/s0165-1218 (96)90123-8

GRIFFIN NJ, PALMER CG and SCHERMAN P-A (2014) Critical analysis of environmental water quality in South Africa: historic and current trends. WRC Report No. 2184/1/14. Water Research Commission, Pretoria. 
GRISCOM SB, FISCHER NS and LUOMA SN (2000) Geochemical influences on assimilation of sediment-bound metals in clams and mussels. Environ. Sci. Technol. 34 91-99. https://doi.org/10.1021/ es981309+

GRUMMT T (2000) DNA repair synthesis (unscheduled DNA synthesis) as a parameter for the assessment of genotoxicity in surface water combined with microbiologic and cell biologic methods. In: Grummt T (ed.) Erprobung, Vergleich, Weiterentwicklung und Beurteilung von Gentoxizitätstests für Oberflächenwasser. Forschungszentrum Karlsruhe GmbH, Projektträger Wassertechnologie und Entsorgung. Außenstelle, Dresden. 217.

GÜNTHER P, MAREE JP, STROBOS G and MTIMIKULU JS (2003) Neutralisation of acid leachate in a coal processing plant with calcium carbonate. In: Proc. Mine Water and the Environment: $8^{\text {th }}$ International Congress on Mine Water \& the Environment, Johannesburg. 367-382.

GUO D, MA J, SU W, XIE B and GUO C (2014) Contribution of reactive oxygen species (ROS) to genotoxicity of Nitrobenzene on V. faba. Ecotoxicology. 23 657-664. https://doi.org/10.1007/s10646-014-12 $30-\mathrm{x}$

GUSSO-CHOUERI PKX, CHOUERI RB, SANTOS GS, SERAPHIM DE ARAÚJO G, CRUZ ACF, STREMEL T, XAVIER DE CAMPOS S CESTARI MM, RIBEIRO CAO and ABESSA DMS (2016) Assessing genotoxic effects in fish from a marine protected area influenced by former mining activities and other stressors. Mar. Pollut. Bull. 104 229-239.

HAYASHI M, KUGE T, ENDOH D, NAKAYAMA K, ARIKAWA J, TAKAZAWA A and OKUI T (2000). Hepatic copper accumulation induces DNA strand breaks in the liver cells of Long-Evans Cinnamon strain rats. Biochem. Biophys. Res. Commun. 276 174178. https://doi.org/10.1006/bbrc.2000.3454

HUIZENGA JM (2011) Characterisation of the inorganic chemistry of surface waters in South Africa. Water SA. 37 401-410. https://doi. org/10.4314/wsa.v37i3.68491

IJI OT, SEREM JC, BESTER MJ, VENTER EA, MYBURGH JG and MCGAW LJ (2017) Generation of reactive oxygen species in relevant cell lines as a bio-indicator of oxidative effects caused by acid mine water. Water SA. 43 166-174. http://dx.doi.org/10.4314/wsa.v43i1.18

JARVIS AP and YOUNGER PL (2001) Passive treatment of ferruginous mine waters using high surface area media. Water Res. 353643 3648. https://doi.org/10.1016/S0043-1354(01)00089-6

JENNINGS, SR, NEUMAN DR and BLICKER PS (2008) Acid Mine Drainage and Effects on Fish Health and Ecology: A Review. Reclamation Research Group Publication, Bozeman, MT.

JOHNSON DB and HALLBERG KB (2005) Acid mine drainage: Remediation options. Sci. Total Environ. 338 3-14. https://doi.org/ 10.1016/j.scitotenv.2004.09.002

KARATHANASIS AD and JOHNSON CM (2003) Metal removal potential by three aquatic plants in an acid mine drainage wetland. Mine Water Environ. 2 22-30. https://doi.org/10.1007/s10 2300300004

KARBOWNIK M and LEWIŃSKI A (2003) Melatonin reduces Fenton reaction-induced lipid peroxidation in porcine thyroid tissue. J. Cell. Biochem. 90 806-811. https://doi.org/10.1002/jcb.10689

KIENZLER A, TRONCHËE X, ALAIN D and BONY S (2013) UVinduced Nucleotide Excision Repair (NER) and Photoreactivation Repair (PER) in two trout fish cell lines used in ecotoxicological assessment studies. J. Photochem. Photobiol. B Biol. 125C 51-55. https://doi.org/10.1016/j.jphotobiol.2013.05.004

KIFFNEY PM and CLEMENTS WH (1994) Effects of heavy metals on a macroinvertebrate assemblage from a Rocky Mountain stream in experimental microcosms. J. N. Am. Benthol. Soc. 13 511-523. https://doi.org/10.2307/1467847

KLOBUCAR GIV, PAVLICA M, ERBEN R and PAPES D (2003) Application of the micronucleus and Comet assays to mussel Dreissena polymorpha haemocytes for genotoxicity monitoring of freshwater environments. Aquat. Toxicol. 64 15-23. https://doi. org/10.1016/s0166-445x(03)00009-2

MADEIRA VS, ECHERT AB, SCHNEIDER CH and SCHNEIDER IAH (2005) Sulphate reduction in acid mine drainage through anaerobic treatment with sulphate reducing bacteria. In: Proceedings of the XXI Ores National Treatment Dating Extractive Agents metallurgy and interference processes, degradation, and environmental damage management in $S A$.
MARON DM and AMES BN (1983) Revised methods for the Salmonella mutagenicity test. Mutat. Res. 113 173-215. https:/doi. org/10.1016/0165-1161(83)90010-9

MATSUMOTO ST, MANTOVANI, MS, MALAGUTTII MIA, DIAS AL, FONSECA IC, and MARIN-MORALES MA (2006) Genotoxicity and mutagenicity of water contaminated with tannery effluents, as evaluated by the micronucleus test and comet assay using the fish Oreochromis niloticus and chromosome aberrations in onion roottips. Genet. Mol. Biol. 29 148-158. http://dx.doi.org/10.1590/S141547572006000100028

MENEZES APS DA SILVA, ROSSATO J, SANTOS RR, DECKER MS SILVA NDA, CRUZ FR, DIHL C LEHMANN RR and FERRAZ ABF (2015) Genotoxic and biochemical changes in Baccharis trimera induced by coal contamination. Ecotoxicol. Environ. Saf. 114 9-16. https://doi.org/10.1016/j.ecoenv.2015.01.001

MILLENNIUM ECOSYSTEM ASSESSMENT (2005) Ecosystems and Human Well-being: Synthesis. Island Press, Washington DC. ISBN 1-59726-040-1.

MEND (Mine Environment Neutral Drainage) (1999) Review of passive systems for treatment of acid mine drainage; MEND Report 3.14.1; MEND Program: Toronto, ON, Canada.

MORALEJO MDP and ACEBAL SG (2014) The transfer of $\mathrm{Cu}, \mathrm{Zn}$, $\mathrm{Mn}$ and $\mathrm{Fe}$ between soils and Allium plants (garlic and onion), and tomato in the Southwest of the Buenos Aires Province, Argentina. Am. J. Plant Sci. 5 480-487. http://dx.doi.org/10.4236/ ajps.2014.54062

NAGARATHNA PKM, WESLEY J, REDDY PS and REENA K (2013) Review on genotoxicity, its molecular mechanisms and prevention. Int. J. Pharm. Sci. Rev. Res. 22 236-243. ISSN 0976 - 044X.

OBERHOLSTER PJ, MYBURGH JG, ASHTON PJ, COETZEE JJ and BOTHA A-M (2012) Bioaccumulation of aluminium and iron in the food chain of Lake Loskop, South Africa. Ecotoxicol. Environ. Saf. 75 134-141.

OHE T, WATANABE T and WAKABAYASHI K (2004) Mutagens in surface waters: a review. Mutat. Res. 567 109-149. https://doi. org/10.1016/j.mrrev.2004.08.003

OLIVEIRA M, PACHECO M and SANTOS MA (2008) Organ specific antioxidant responses in golden grey mullet (Liza aurata) following a short-term exposure to phenanthrene. Sci. Total Environ. 3970 78. DOI: https://doi.org/10.1016/j.scitotenv.2008.02.012

PASTORIZA TF, MARQUES DM, LEMOS CT, TERRA NR and VARGAS VMF (2006) Genotoxicity and toxicity assessment in urban hydrographic basins. Mutat. Res. 603 83-96. https://doi.org/ 10.1007/s11356-014-3476-5

PEARSON H, SHADDOCK BF, MULDER PFS and CLOETE YC (2015) Development of research support to enable the issuing of aquatic toxicity-based water use licenses: Guideline document. WRC Report No. KV 347/15. Water Research Commission, Pretoria.

RADIĆ S, VUJČIĆ V, CVETKOVIĆ Z, CVJETKO P and OREŠČANIN $\mathrm{V}$ (2014) The efficiency of combined CaO/electrochemical treatment in removal of acid mine drainage induced toxicity and genotoxicity. Sci. Total Environ. 466-467 84-89. https://doi.org/10.1016/j.scito tenv.2013.07.011

ROBBIANO L, BARONI D, CARROZZINO R, MERETO E and BRAMBILLA G (2004) DNA damage and micronuclei induced in rat and human kidney cells by six chemicals carcinogenic to the rat kidney. Toxicology. 204 187-195. ISSN 0300-483X.

ROSEMOND AD, REICE SR, ELWOOD JW and MULHOLLAND PJ (1992) The effects of stream acidity on benthic invertebrate communities in the south-eastern United States. Freshwater Biol. 27 193-209. https://doi.org/10.1111/j.1365-2427.1992.tb00533.x

SCHERMAN PA, MULLER WJ and JOOSTE S (2004) A further investigation into using a risk-based approach for setting integrated environmental objectives for the protection of water resources. WRC Report No. KV 154/04. Water Research Commission, Pretoria.

SCHWAB R (2002) Government experiences with mine closure: meeting objectives rather than actions. WISA Mine Water Division. Mine Closure Conference, 23-24 October 2002, Randfontein.

SHAKIBAIE MR, JALILZADEH KA and YAMAKANAMARDI SM (2009) Horizontal transfer of antibiotic resistance genes among Gram negative bacteria in sewage and lake water and influence of some physico-chemical parameters of water on conjugation process. J. Environ. Biol. 30 45-49. https://doi.org/10.1371/journal. pone. 0148098 
SINGH NP, MCCOY MT, TICE RR and SCHNEIDER EL (1988) A simple technique for quantitation of low levels of DNA damage in individual cells. Exp. Cell Res. 175 184-191. https://doi.org/ 10.1016/0014-4827(88)90265-0

SOUCEK DJ, CHERRY DS, CURRIE RJ, LATIMER HA and TRENT GC (2000) Laboratory to field validation in an integrative assessment of an acid mine drainage-impacted watershed. Environ. Toxicol. Chem. 19 1036-1043. https://doi.org/10.1002/etc.5620190433

STAHL RG (1991) The genetic toxicology of organic compounds in natural waters and wastewaters. Ecotoxicol. Environ. Saf. 22 94-125. https://doi.org/10.1016/0147-6513(91)90051-p

STEYN M, OBERHOLSTER PJ, BOTHA AM, GENTHE B, VAN DEN HEEVER-KRIEKPE and WEYERS C (2019) Treated acid mine drainage and stream recovery: Downstream impacts on benthic macroinvertebrate communities in relation to multispecies toxicity bioassays, stream acidity on benthic invertebrate communities in the south-eastern United States. J. Environ. Manage. 235 377-388.

TALUKDAR B, KALITA HK, BAISHA RA, BASUMATARY S and SARMA D (2016) Evaluation of genetic toxicity caused by acid mine drainage of coal mines on fish fauna of Simsang River, Garohills, Meghalaya, India. Ecotoxicol. Environ. Saf. 131 65-71. https://doi. org/10.1016/j.ecoenv.2016.05.011

TALUKDAR B, KALITA HK, BASUMATARY S, SAIKIA DJ and SARMA D (2017) Cytotoxic and genotoxic effects of acid mine drainage on fish Channa punctata (Bloch). Ecotoxicol. Environ. Saf. 144 72-78. https://doi.org/10.1016/j.ecoenv.2017.06.007

TAMIRES MD, FERNANDA ZD, TIAGO B, REGINALDO G, JAIRO JZ and CLAUS TP (2009) Evaluation of acid mine drainage treatment using Artemia sp. and Allium cepa as bioindicators of toxicity and genotoxicity. Conference: $26^{\text {th }}$ Annual Meetings of the American Society of Mining and Reclamation and $11^{\text {th }}$ Billings Land Reclamation Symposium 2009, Billings, MT. Volume 1. https://doi. org/10.13140/2.1.4068.9929

TRUTER JC, VAN WYK JH, OBERHOLSTER PJ and BOTHA AM (2014). The impacts of neutralized acid mine drainage contaminated water on the expression of selected endocrine-linked genes in juvenile Mozambique tilapia Oreochromis mossambicus exposed in vivo. Ecotoxicol. Environ. Saf. 100 209-217. ISSN 0147-6513.
TÜRKER OC, BCÜK H and YAKAR A (2013) The phytoremediation ability of a polyculture constructed wetland to treat boron from mine effluent. J. Hazardous Mater. 252 132-141. https://doi.org/10.1016/j. jhazmat.2013.02.032

USEPA (United States Environmental Protection Agency) (1993) Constructed wetland for wastewater treatment 17 case studies. EPA832-R-93-005.

USEPA (United States Environmental Protection Agency) (2000a) Supplementary Guidance for Conducting Health Risk Assessment of Chemical Mixtures. EPA/630/R-00/002. USEPA, Washington D.C.

VALKO M, LEIBFRITZ D, MONCOL J, CRONIN MT, MAZUR M and TELSER J (2007) Free radicals and antioxidants in normal physiological functions and human disease. Int. J. Biochem. Cell Biol. 39 44-84. https://doi.org/10.1016/j.biocel.2006.07.001

VERSCHAEVE L and VAN STADEN J (2008) Mutagenic and antimutagenic properties of extracts from South African traditional medicinal plants. J. Ethnopharmacol. 119 575-587. https://doi.org/ 10.1016/j.jep.2008.06.007

WEPENER V and CHAPMAN PM (2012) South African ecotoxicology - present status and future prognosis. Afr. J. Aquat. Sci. 37 (3) 229-234. https://doi.org/10.2989/16085914.2012.717051

WIJEYARATNE WMDN and WICKRAMASINGHE PGMU (2020) Treated textile effluents: cytotoxic and genotoxic effects in the natural aquatic environment. Bull. Environ. Contam. Toxicol. 104 245-252. https://doi.org//10.1007/s00128-019-02768-x

YOUNGER PL, BANWART SA and HEDIN RS (2002) Passive treatment of polluted mine waters. In: Mine Water; Environmental Pollution. Volume 5. Springer, Dordrecht. 311-396. https://doi.org/ 10.1007/978-94-010-0610-1_5

ZALASIEWICZ J, WILLIAMS M, STEFFEN W and CRUTZEN $P$ (2010) The New World of the Anthropocene. Environ. Sci. Technol. 44 2228-2231. https://doi.org//10.1021/es903118j 